\title{
Haptoglobin Gene Polymorphisms in Sickle Cell Disease Patients with Different $\beta^{\mathrm{S}}$-Globin Gene Haplotypes
}

\author{
A.D. Adekile M.Z. Haider \\ Department of Paediatrics, Faculty of Medicine, Health Sciences Centre, Kuwait University, Kuwait
}

\section{Key Words}

Haptoglobin gene $\cdot$ Sickle cell disease $\cdot$ Genotype

\begin{abstract}
Objective: To investigate the prevalence of haptoglobin $(\mathrm{Hp})$ gene alleles in Kuwaiti sickle cell disease (SCD) patients, who generally have a mild phenotype, and compare the pattern to Nigerian SCD patients whose SCD phenotype is more severe. Subjects and Methods: $\mathrm{Hp}$ genotyping was carried out in a group of 82 and 54 SCD patients from Kuwait and Nigeria, respectively, and appropriate $\mathrm{Hb}$ AA controls. The Hp genotyping was done using a PCR technique followed by agarose gel electrophoresis. Results: The frequency of the $\mathrm{Hp}-2$ allele was $73.8 \%$ among Kuwaiti SCD patients, while the Hp-1 allele predominated among Nigerian patients (60.7\%). However, the differences were not significant $(p>0.05)$ when the allele distributions were compared between Kuwaiti SCD and their AA counterparts or between Nigerian SCD and their AA controls. There was no association of $\mathrm{Hp}-2$ allele with frequent vaso-occlusive crisis among the Kuwaiti SCD patients. Conclusion: The distribution of Hp alleles appears to follow ethnic and geographical trends. Their role in the pathophysiology of pain crisis is not clear.
\end{abstract}

Copyright $\odot 2010$ S. Karger AG, Basel

\section{Introduction}

Sickle cell disease (SCD), like other chronic hemolytic states, is characterized by a release of excess free heme, which catalyzes the formation of reactive oxygen spe-

\section{KARGER}

Fax +4161306 1234

E-Mail karger@karger.ch

www.karger.com
(C) 2010 S. Karger AG, Basel

1011-7571/10/0196-0447\$26.00/0

Accessible online at:

www.karger.com/mpp cies and produces oxidative stress $[1,2]$. Heme induces the expression of pro-inflammatory adhesion molecules both in vitro and in vivo [3-5]. Indeed, SCD vasculopathy and vaso-occlusion are believed to be secondary to such adhesive interactions between circulating blood cells and the endothelium. There is consequent nitric oxide scavenging, leading to smooth muscle dystonia and intimal thickening. Some SCD subphenotypes - e.g. pulmonary hypertension, priapism, stroke, and leg ulceration - are more common in SCD patients with low Hb F levels who have a severer degree of hemolysis [2]. However, SCD patients with high $\mathrm{Hb} \mathrm{F}$ levels tend to have a lesser degree of hemolysis with a higher hematocrit count $[6,7]$. Consequently, they present more with thrombotic complications like severe frequent vaso-occlusive episodes, osteonecrosis and acute chest syndrome $[8,9]$. The overall influence of free heme on SCD pathophysiology is probably affected by functional polymorphisms in key enzymes involved in different pathways of iron transport or catabolism and in the oxidative stress that it generates.

The first-line scavenger of free plasma $\mathrm{Hb}$ is haptoglobin (Hp), to which it is rapidly bound following its release. The Hb-Hp complex exposes a neoepitope that is recognized by the $\mathrm{Hb}$ scavenger receptor, $\mathrm{CD} 163$, on the surface of monocytes and macrophages through which the complexes are endocytosed and degraded [10]. Hp is an $\alpha$-sialoglycoprotein found in all mammals, but exhibiting a polymorphism only in humans, in whom $3 \mathrm{ma}-$ jor functional phenotypes have been described: Hp 1-1, Hp 2-2 and the heterozygous Hp 2-1. Hp 1-1 is the most biologically active in binding free $\mathrm{Hb}$ and suppressing consequent inflammatory responses; Hp 2-2 is the least 
biologically active while Hp 2-1 is intermediate [11, 12]. $\mathrm{Hp}$ allele frequencies follow marked geographical and ethnic distributions, such that the lowest Hp-1 allele frequency is found in southeast Asia and the greatest frequency in Africa and South America [11, 13-15].

There have been several studies associating Hp phenotypes with different clinical conditions. $\mathrm{Hp} 2-2$ is associated with myocardial infarction as an independent predictor of the severity and extent of myocardial damage in patients with different risk factors [16]. Hp 1-1 protects against atherosclerosis and other vascular complications of diabetes mellitus and is also protective in retinal hemorrhage $[17,18]$. There are two previous studies of $\mathrm{Hp}$ phenotypes in SCD, one from the USA [19] and the other from Brazil [20], both of which reported a strong association with Hp 1-1 phenotype. Although there was no mention of the $\beta^{\mathrm{S}}$-globin gene haplotypes in the patients, it is known that SCD in both populations is associated with haplotypes characterized by low $\mathrm{Hb}$ F. Moreover, the two groups of patients share similar ancestral histories, being descendants of Africans brought to the Americas as slaves. The present study was therefore designed to investigate the pattern of Hp phenotypes in SCD patients from two distinct geographical groups (Kuwait and Nigeria) and different $\beta^{S}$ haplotypes and clinical phenotypes. The study was approved by the Institutional Human Research Ethics Committee, Faculty of Medicine, Health Sciences Centre, Kuwait University, Kuwait.

\section{Subjects and Methods}

Kuwaiti SCD Patients and Controls

Eighty-two Kuwaiti SCD patients and 49 AA controls were enrolled in the study. The SCD patients were being followed in the Hematology Clinic in Mubarak Al-Kabeer and Al-Amiri hospitals. Routine complete blood cell counts and cation-exchange HPLC were carried out and DNA extracted. All were screened for $\beta^{S}$ haplotypes; Hb AA siblings were used as controls. All the SCD patients were $\mathrm{Hb}$ SS, carrying the Arab/India (AI) haplotype. The severity of the SCD was determined by reviewing the patients' hospital charts. Those who had been hospitalized $\geq 4$ times in the previous year because of vaso-occlusive crisis (VOC) were classified as a having a severe phenotype.

\section{Nigerian SCD Patients and Controls}

Fifty-four Nigerian SS patients and 32 AA controls from Ile-Ife (Osun State) and Benin (Bendel State), both in Southern Nigeria, were enrolled in the study. They were part of a large previous study characterizing the $\beta^{\mathrm{S}}$-globin gene cluster haplotypes among Nigerian SCD patients [21]. Blood was also collected from nonSCD siblings of the patients as controls. Complete blood count was done on all samples and the $\mathrm{Hb}$ genotype was confirmed using cation exchange HPLC [22]. DNA was extracted with the method of Poncz et al. [23] and the $\beta^{S}$ haplotype determined using standard techniques [24]. DNA samples were stored frozen at $-70^{\circ} \mathrm{C}$. Only patients who were $\mathrm{Hb}$ SS and carried the Benin (BEN) haplotype were selected for Hp study.

\section{Hp Genotyping}

Hp genotypes were characterized using PCR amplification of DNA segments representing the $\mathrm{Hp}-1$ and $\mathrm{Hp}-2$ alleles, followed by agarose gel electrophoresis [25].

\section{Data Analysis}

The frequencies of the genotypes and individual alleles are presented as percentages. Comparisons were made within and between groups using the $\chi^{2}$ test. Relative risk was calculated to test allele association with severity index among Kuwaiti SCD patients.

\section{Results}

The Kuwaiti subjects were all homozygous for the AI haplotype, while the Nigerians were homozygous for the BEN haplotype. The Hp genotype frequencies of the different groups are shown in table 1. Among the Kuwaitis, the distribution was similar in the SS patients and controls $\left(\chi^{2}=0.50, p=0.78\right)$. Also among the Nigerians, there was no significant difference in the distribution between the SS and the AA controls $\left(\chi^{2}=1.8, \mathrm{p}=0.41\right)$. However, when the Kuwaiti SS patients were compared to the Nigerian SS patients, the difference was highly significant $\left(\chi^{2}=31.4, \mathrm{p}=0.00\right)$. Hp 2-2 was most prevalent among Kuwaitis compared to Nigerian patients (52.4 and 16.7\%, respectively). On the other hand, Hp 1-1 was found in $4.9 \%$ of Kuwaiti SS and in $37.5 \%$ of Nigerian SS patients while the figures in the control subjects were 4.9 and $38.9 \%$, respectively. The intra-group differences were not statistically significant $(p>0.05)$. There were also no significant differences when the Nigerian individuals were divided according to their state of origin.

The frequencies of the individual Hp alleles in the different groups are given in table 2. Among the $\mathrm{Ku}$ waitis, Hp-2 was most prevalent (73.8 and $71.4 \%$ in SS and controls, respectively). In the Nigerian group, $\mathrm{Hp}-1$ allele was most common (60.7 and $54.7 \%$ in SS and controls, respectively). The difference among the Kuwaiti SS and Nigerian SS is highly significant $\left(\chi^{2}=32.9, \mathrm{p}=0.000\right)$. The same degree of significance was found when the distributions among the Kuwaiti and Nigerian AA controls were compared $\left(\chi^{2}=11.1, p=0.001\right)$. However, the differences between Kuwaiti SS and AA controls and between Nigerian SS and AA controls were not significant.

The Kuwaiti SS patients were classified according to whether or not they had frequent severe VOC, and the 
Table 1. Frequencies of Hp polymorphisms

\begin{tabular}{lcccc}
\hline Genotype & $\begin{array}{l}\text { Kuwaiti } \\
\text { SCD }\end{array}$ & $\begin{array}{l}\text { Kuwaiti } \\
\text { Hb AA }\end{array}$ & $\begin{array}{l}\text { Nigerian } \\
\text { SCD }\end{array}$ & $\begin{array}{l}\text { Nigerian } \\
\text { Hb AA }\end{array}$ \\
\hline $2-2$ & $43(52.4)$ & $23(46.9)$ & $9(16.7)$ & $9(28.1)$ \\
$2-1$ & $35(42.7)$ & $24(49.0)$ & $24(44.4)$ & $11(34.4)$ \\
$1-1$ & $4(4.9)$ & $2(4.1)$ & $21(38.9)$ & $12(37.5)$ \\
Total & $82(100.0)$ & $49(100.0)$ & $54(100.0)$ & $32(100.0)$ \\
\hline
\end{tabular}

Figures in parentheses are percentages.

Table 2. Frequencies of Hp alleles

\begin{tabular}{llrr}
\hline Group & Hp-1 & Hp-2 & Total \\
\hline Kuwaiti SCD & $43(26.2)$ & $121(73.8)$ & 164 \\
Kuwaiti Hb AA & $28(28.6)$ & $70(71.4)$ & 98 \\
Nigerian SCD & $68(60.7)$ & $44(39.3)$ & 112 \\
Nigerian Hb AA & $35(54.7)$ & $29(45.3)$ & 64 \\
\hline
\end{tabular}

Figures in parentheses are percentages.

Table 3. Association of $\mathrm{Hp}$ alleles with frequency of VOC in $\mathrm{Ku}$ waiti SCD patients

\begin{tabular}{lrll}
\hline VOC admissions & Hp-1 & Hp-2 & Total \\
\hline$>4$ & $5(19.2)$ & $21(80.8)$ & $26(100.0)$ \\
$\leq 4$ & $10(31.2)$ & $22(68.8)$ & $32(100.0)$ \\
Total & $15(25.9)$ & $43(74.1)$ & $58(100.0)$ \\
\hline
\end{tabular}

Figures in parentheses are percentages.

distribution of Hp alleles is shown in table 3. There was no significant difference in the frequencies of the $\mathrm{Hp}$ alleles $\left(\chi^{2}=1.08, p=0.29\right)$ and no significant association of $\mathrm{Hp}-2$ allele with increased VOC frequency with a relative risk of 1.5 (CI 0.67-3.19).

\section{Discussion}

Kuwaiti SCD patients carry the AI $\beta^{S}$ haplotype with elevated $\mathrm{Hb} \mathrm{F}$ and generally have a mild clinical course $[8$, 26]. They retain normal spleen function, and complications like stroke, acute chest syndrome, priapism and leg ulcers are uncommon [27, 28]. However, there is a subset of patients with frequent severe VOC and a high preva- lence of osteonecrosis $[8,9]$. It appears, therefore, that although Kuwaiti patients have a uniformly high $\mathrm{Hb} F$ with consequent reduced rates of hemolysis, the inflammatory response is heterogeneous. On the other hand, Nigerian SCD patients are characterized by a predominance of the BEN haplotype and low Hb F levels. The disease phenotype is severe with a high incidence of hand/foot syndrome, pulmonary hypertension, acute chest syndrome and neurological complications [7]. However, even among these patients, the phenotype is quite variable. There is a need, therefore, to explore the downstream consequences of the SCD pathophysiology to identify other gene polymorphisms that modulate the disease phenotype. This underscores the need for inter-ethnic studies of SCD patients with different geographical and genetic backgrounds, and is the rationale for comparing Kuwaiti to Nigerian SCD patients in the present study.

$\mathrm{Hp}$, in addition to its avid $\mathrm{Hb}$-binding capability, acts as an antioxidant, has antibacterial properties, and also plays a role in modulating many aspects of the acute phase response $[29,30]$. Its $\mathrm{Hb}$ binding, oxidative capacity and inhibition of prostaglandin are strongest in Hp 1-1, weakest in $\mathrm{Hp} 2-2$, and intermediate in Hp 2-1 phenotypes [31, 32]. Because of this polymorphism, the $\mathrm{Hp}$ gene is a prime candidate of investigation for any modulatory association with SCD pathophysiology or its subphenotypes. The only previous pertinent studies have been among American and Brazilian patients, for both of whom an association with the Hp 1-1 phenotype was reported $[19,20]$. The current study is the first among Arab and African SCD patients. It is therefore interesting that there is such a distinct difference in the prevalent $\mathrm{Hp}$ alleles in the two populations. Among Kuwaiti patients, $\mathrm{Hp}-2$ allele is seen in $73.8 \%$, while among Nigerian patients, $\mathrm{Hp}-1$ predominates at a prevalence of $60.7 \%$. However, when the prevalence was compared between patients and AA controls in each population, there was no significant difference. This therefore raises the possibility that whatever difference between Kuwaiti and Nigerian SCD patients is due to ethnic and geographic segregation. Indeed, previous studies from large samples of healthy Nigerians reported a Hp-1 frequency of about $60 \%$ and studies from the Middle East, including Arabs, found a prevalence of $\mathrm{Hp}-2$ allele of about $70 \%$, similar to what we found in the present study.

The present study also afforded an opportunity to examine the association of the Hp polymorphism with frequent VOC among Kuwaiti SS patients. Perhaps because of the small number of patients, there was no significant association of Hp-2 allele with increased risk for severe VOC. Unfortunately, the Nigerian patients were not stratified ac- 
cording to frequency of VOC. It is, however, interesting that the $\mathrm{Hp}-1$ allele, which is associated with high $\mathrm{Hb}$ binding, is the predominant allele among Nigerian patients, in whom the rate of hemolysis is higher than in Kuwaitis.

\section{Conclusion}

Hp allele distribution in Kuwaiti and Nigerian SCD patients is similar to that described in the normal populations from the same geographical locations. There is still a place for further studies of $\mathrm{Hb}$ polymorphism in the different subphenotypes of SCD, especially pulmonary hypertension, acute chest syndrome, priapism and leg ulcers.

\section{Acknowledgements}

The authors thank all their colleagues, especially those in $\mathrm{Ni}$ geria, for allowing them to include their patients in this study. The technical assistance of Mrs. Jalaja Sukumaran is appreciated.

\section{References}

$\checkmark 1$ Aslan M, Thornley-Brown D, Freeman BA: Reactive species in sickle cell disease. Ann N Y Acad Sci 2000;899:375-391.

-2 Kato GJ, Gladwin MT, Steinberg MH: Deconstructing sickle cell disease: reappraisal of the role of hemolysis in the development of clinical subphenotypes. Blood Rev 2007; 21:37-47.

- 3 Wagener FADTG, Feldman E, de Witte T, Abraham NG: Heme induces the expression of adhesion molecules ICAM-1, VCAM-1 and E-selectin in vascular endothelial cells. Proc Soc Exp Biol Med 1997;216:456-463.

-4 Wagener FADTG, Abraham NG, van Kooyk Y, de Witte T, Figdor CG: Heme-induced cell adhesion in the pathogenesis of sickle-cell disease and inflammation. Trends Pharmacol Sci 2001;22:52-54.

-5 Al-Saqladi AW, Delpisheh AW, Bin-Gadeem $\mathrm{H}$, Brabin BJ: Clinical profile of sickle cell disease in Yemeni children. Ann Trop Paediatr 2007;27:253-259.

-6 Powars DR, Chan L, Schroeder WA: The influence of fetal hemoglobin on the clinical expression of sickle cell anemia. Ann N Y Acad Sci 1989;565:262-278.

7 Powars DR: Sickle cell anemia: $\beta^{\mathrm{S}}$-gene-cluster haplotypes as prognostic indicators of vital organ failure. Semin Hematol 1991;28 202-208.

-8 Adekile AD, Haider MZ: Morbidity, $\beta^{\mathrm{S}}$ haplotypes and $\alpha$-globin gene patterns in SS patients from Kuwait. Acta Haematol 1996;96 150-154.

-9 Adekile AD, Gupta R, Yacoub F, Sinan T, Al-Bloushi M, Haider MZ: Avascular necrosis of the hip in kuwaiti children with sickle cell disease: MRI images and association with $\alpha$-thalassemia trait. Acta Haematol 2001;105:27-31.

10 Kristiansen M, Graversen JH, Jacobsen C, Sonne O, Hoffman HJ, Law SK, Moestrup SK: Identification of the haemoglobin scavenger receptor. Nature 2001;409:198-201.

-11 Langlois MR, Delanghe JR: Biological and clinical significance of haptoglobin polymorphism in humans. Clin Chem 1996;42: 1589-1600.
12 Van Vlierberghe H, Langlois M, Delanghe J: Haptoglobin polymorphisms and iron homeostasis in health and in disease. Clin Chim Acta 2004;345:35-42.

13 Constans J, Viau M, Gouaillard C, Clerc A: Haptoglobin polymorphism among Saharian and West African groups: haptoglobin phenotype determination by radioimmunoelectrophoresis on $\mathrm{Hp} \mathrm{O}$ samples. Am J Hum Genet 1981;33:606-616.

14 Farhund DD: Haptoglobin polymorphism in the Middle East. J Hum Genet 1980;25:203206.

15 Danubio ME, Anelli A: ABO, Rh(D) and haptoglobin distribution in a sample from the Sultanate of Oman. Int J Anthropol 1987; 2:77-81.

$\longrightarrow 16$ Roguin A, Hochberg I, Nikolsky E, Markiewicz W, Meisel SR, Hir J, Grenadier E, Beyar R, Levy AP: Haptoglobin phenotype as a predictor of restenosis after percutaneous transluminal coronary angioplasty. Am J Cardiol 2001:87:330-332.

17 Levy AP, Roguin A, Hochberg I, Herer P, Marsh S, Nakhoul FM, Skorecki K: Haptoglobin phenotype and vascular complications in patients with diabetes. N Engl J Med 2000;343:969-970.

-18 Nakhoul F, Marsh S, Hochberg I, Leibu R, Miller BP, Levy AP: Haptoglobin genotype as a risk factor for diabetic retinopathy. JAMA 2000;284:1244-1245.

19 Ostrowski RS, Travis JC, Talley ES: The association of $\mathrm{Hp} 1$ and sickle cell disease. Hum Hered 1987;37:193-195.

20 Moreira HW, Naoum PC: Serum haptoglobin types in patients with hemoglobinopathies. Hereditas 1990;113:227-231.

-21 Adekile AD, Kitundu MN, Gu L-H, Adeodu OO, Huisman THJ: Sickle Cell anemia in Nigeria: $\beta S$ haplotypes among nigerians; characterization of a haplotype 19 (Benin) with elevated $\mathrm{Hb} \mathrm{F}$ and $\mathrm{G} \gamma$ levels. Ann Hematol 1992;65:41-45.

22 Bissé E, Wieland H: High-performance chromatographic separation of human haemoglobins: Simultaneous quantitation of foetal and glycated haemoglobins. J Chromatogr 1988;434:95-110.
23 Poncz M, Solowiejczyk D, Harpel B, Mory Y, Schwartz E, Surrey S: Construction of human gene libraries from small amounts of peripheral blood: analysis of $\beta S$-like globin genes. Hemoglobin 1982;6:27-36.

24 Lanclos KD, Oner C, Dimovski AJ, Gu Y-C Huisman THJ: Sequence variations in the $5^{\prime}$ flanking and IVS-II regions of the ${ }^{\mathrm{G}} \boldsymbol{\gamma}$ - and ${ }^{\mathrm{A}} \gamma$-globin genes of the $\beta^{\mathrm{S}}$ chromosomes with five different haplotypes. Blood 1991;77: 2488-2496.

25 Koch W, Latz W, Eichinger M, Roguin A, Levy AP, Schomig A, Kastrati A: Genotyping of the common haptoglobin Hp 1/2 polymorphism based on PCR. Clin Chem 2002; 48:1377-1382.

-26 Adekile AD, Gu L-H, Baysal E, Haider MZ, Al-Fuzae L, Aboobacker KC, Al-Rashied A, Huisman THJ: Molecular characterization of $\alpha$-thalassemia determinants, $\beta$-thalassemia alleles and $\beta^{\mathrm{S}}$ haplotypes among Kuwaiti Arabs. Acta Haematol 1994;92:176-181.

- 27 Adekile AD, Yacoub F, Gupta R, Sinan T, Al-Bloushi M, Haider M Z, Habib Y, Moosa A: Silent brain infarcts are rare in Kuwaiti children with sickle cell disease and high $\mathrm{Hb}$ F. Am J Hematol 2002;70:228-231

- 28 Adekile AD, Owunwanne A, Al-Za'abi K, Haider MZ, Tuli M, Al-Mohannadi S: Temporal sequence of splenic dysfunction in sickle cell disease. Am J Hematol 2002;69: 23-27.

29 Gutteridge JM: The antioxidant activity of haptoglobin towards haemoglobin-stimulated lipid peroxidation. Biochim Biophys Acta 1987;917:219-223.

30 Eaton JW, Brandt P, Mahoney JR: Haptoglobin: a natural bacteriostat. Science 1982;215: 691-693.

31 Jue DM, Shim BS, Kang YS: Inhibition of prostaglandin synthase activity of sheep seminal vesicular gland by human serum haptoglobin. Mol Cell Biochem 1983;51:141147.

32 Setty BN, Kulkarni S, Dampier CD, Stuart MJ: Fetal hemoglobin in sickle cell anemia: relationship to erythrocyte adhesion markers and adhesion. Blood 2001;97:2568-2573. 